\title{
A REALIDADE DA INFORMÁTICA NA EDUCAÇÃO EM ESCOLA PÚBLICA ESTADUAL DA REGIÃO METROPOLITANA DE BELO HORIZONTE - UM ESTUDO DE CASO
}

Dejanir José CAMPOS JÚNIOR ${ }^{1}$

\begin{abstract}
RESUMO: Este estudo propôs-se a investigar, discutir e refletir acerca da introdução da informática na educação e mais especificamente a investigar a utilização do laboratório de informática em uma escola da rede pública estadual de Minas Gerais. Sabendo que tal questão vem sendo amplamente discutida, propô-se também a buscar em situações reais de utilização, subsídios que permitissem discutir a introdução da informática na educação. Para tanto, optou-se por realizar um Estudo de Caso em uma escola pública estadual na região metropolitana de Belo Horizonte. Utilizou-se ainda, questionários semi estruturados que foram respondidos pelos professores e pedagogos da escola citada, além de entrevistas informais com os professores a fim de se detectar o entrosamento entre professores e novas tecnologias na educação - especificamente a informática. Dessa forma, pretende-se, traçar um verdadeiro perfil dos professores, alunos e laboratórios de informática que estão lotados em escolas "participantes" do Proinfo.
\end{abstract}

PALAVRAS CHAVE: Informática - Educação - Professor

\section{THE REALITY OF COMPUTER EDUCATION IN PUBLIC SCHOOL IN THE STATE OF BELO HORIZONTE METROPOLITAN REGION - A CASE STUDY}

\begin{abstract}
This study aimed to investigate, discuss and reflect on the introduction of computers in education and more specifically to investigate the use of the computer lab in a public school in the state of Minas Gerais. Knowing that this issue has been widely discussed, also propose to seek in real use, subsidies, discusses the introduction of computers in education. To this end, we decided to conduct a case study in a state school in the metropolitan region of Belo Horizonte. Was also used, semi-structured questionnaires that were answered by teachers and educators cited the school as well as informal interviews with teachers in order to detect the disconnect between teachers and new technologies in education - specifically information technology. Thus, it is intended, a true profile of teachers, students and computer labs that are assigned to schools participating in the Proinfo.
\end{abstract}

KEY WORDS: Information technology - Education - Teacher

\footnotetext{
${ }^{1}$ Mestre em Educação (UninCor). Especialista em Língua Portuguesa (UNI-BH). Especialista em Educação a Distância (Pitágoras). Licenciado em Letras (PUC-MG). E-mail: dejanirjunior@yahoo.com.br 


\section{INTRODUÇÃO}

Este trabalho propõe-se a investigar, discutir e refletir acerca da introdução da informática na educação e mais especificamente a investigar a utilização do laboratório de informática em uma escola da rede pública estadual de Minas Gerais.

Sabendo que tal questão vem sendo amplamente discutida, tal estudo propõe-se a buscar em situações reais de utilização, subsídios que permitam discutir a introdução da informática na educação. Para tanto, optase por realizar um estudo de caso na Escola Estadual de São Joaquim de Bicas. Pretendese ainda, com este estudo, traçar um verdadeiro perfil dos professores, alunos e laboratórios de informática que estão lotados em escolas "participantes" do Proinfo ${ }^{2}$.

Uma grande questão norteadora deste artigo é, com certeza, a utilização do laboratório de informática na escola. Pretende-se investigar "a quantas anda" a sua utilização.

Tal estudo justifica-se por perceber que as aulas que deveriam tratar da construção do conhecimento com o auxílio de uma nova tecnologia, passaram a ser aulas de pura e limpa informática. Atividades como digitação passaram a fazer parte da nossa aula, o que, de acordo com VALENTE ${ }^{3}$, não passaria de um ensino informatizado, além de constatar, através de discussões que o

\footnotetext{
${ }^{2}$ Proinfo - Programa Nacional de Informática na Educação.

${ }^{3}$ Por quê o computador na educação?, de José Armando Valente.
}

laboratório de informática é tratado como o "espaço morto" da escola, o lugar onde estão entulhados os computadores, que em grande parte nem funcionam.

Assim, a realidade da sociedade atual gera a necessidade de reflexão e mudanças, especialmente na educação, afim de que esta possa desempenhar seu papel na formação do cidadão. Assim, faz-se necessário investigar os motivos pelos quais os laboratórios de informática das escolas públicas de Minas Gerais, agraciadas pelo Proinfo, são tão pouco, ou nada utilizados e o porquê destas salas serem consideradas como o "espaço morto" da escola, uma vez que um laboratório de informática na escola é um sonho de muitos.

\section{MATERIAIS E MÉTODOS}

Para a coleta de dados que viabilizassem a discussão ora pretendida, foram produzidos dois questionários - um destinado aos professores da Escola Pública Estadual de São Joaquim de Bicas, doravante denominado QUESTIONÁRIO I, e o outro destinado aos orientadores, supervisores, vice diretores e diretor da escola em questão, chamado a partir de agora QUESTIONÁRIO II. É relevante informar que foram pensados dois tipos de questionários, embora com o mesmo objetivo, mas de forma que pudessem coletar dados, às vezes diferentes. Sabemos que as escolas públicas estaduais são grandes centros rotativos de professores em função de 
um processo de contratação chamado designação que aloca os professores na escola tomando como base o seu tempo de trabalho, o que faz com que esses professores, ou grande parte desses professores de uma escola, fiquem um período em um escola e outro período em outro, mas não temos aqui, nenhuma pretensão de analisar e discutir o processo de contratação de professores da rede pública estadual, mas simplesmente tentar justificar o porquê de questionários distintos.

A pesquisa de campo realizada com esses professores e chefes de escolas, tem cunho predominantemente qualitativa, utilizando ainda a pesquisa quantitativa, uma vez que os dados coletados serão estatisticamente tabulados com o propósito de investigar e analisar melhor o que esses profissionais da educação pensam sobre o laboratório de informática na escola e, consequentemente, sobre o uso do computador na sala de aula.

Para facilitar a visualização dos resultados obtidos através dos questionários, apresentaremos esses resultados por meio de gráficos elaborados a partir do programa MICROSOFT EXCEL, em gráficos com formato pizza, em terceira dimensão. Isso para as questões objetivas. Com relação à questão discursiva, esses resultados serão apresentados através de passagens extraídas do próprio texto escrito pelo professor na análise dos resultados.

\section{FUNDAMENTAÇÃO TEÓRICA}

\section{O que é Educação?}

Levando em consideração a área de concentração do mestrado cursado, penso ser necessário tentar definir, ou pelo menos esclarecer, apoiado em alguns autores, o termo educação. Dessa forma, sempre que necessário recorremos a alguns clássicos da literatura e entre eles, apresentaremos a definição de educação apresentada por DURKHEIM (1978), no final do século XIX e início do século XX, uma vez que alguns dos pressupostos propostos pelo autor são bastante atuais e merecem nossa atenção e reflexão.

Com formação em sociologia e pedagogia, DURKHEIM (1978) pensava a educação como um fenômeno "eminentemente social"e resultante da ação exercida por uma geração sobre a geração seguinte a fim de adaptá-la à sociedade em que se vive. Dessa forma DURKHEIM (1978), faz referência a Kant, destacando dele a seguinte afirmação: "o fim da educação é desenvolver, em cada indivíduo toda a perfeição de que ele seja capaz", mas em seguida questiona o termo perfeição, verificando que os ideais de perfeição diferem de uma cultura para outra. Além disso, indivíduos em uma mesma comunidade têm diferentes aptidões e funções a exercer. Assim, o ser humano não segue um modelo único de perfeição e de desenvolvimento, pois, para que cada sociedade seja harmônica, 
"será preciso que haja homens de sensibilidade e homens de ação. ${ }^{4}$

Ou ainda nas palavras de DURKHEIM (1978):

A educação tem variado infinitamente com o tempo e com o meio. Nas cidades gregas e latinas a educação conduzia o indivíduo a subordinar-se cegamente a coletividade, a tornar-se um coisa da sociedade. Hoje, esforça-se para fazer dele uma personalidade autônoma. (...) Na Idade Média a educação era cristã, antes de tudo; Na Renascença toma caráter mais leigo; Nos dias de hoje, a ciência tende a ocupar o lugar que a arte outrora preenchia. (DURKHEIM, 1978, p. 35).

Com vistas na exposição, podemos dizer que DURKHEIM (1978) infere que a educação ideal é construída levando-se em consideração o tempo e o lugar, tornando indispensável a consideração histórica, pois de acordo com o autor o passado de uma humanidade contribui diretamente para o estabelecimento de um grupo de princípios que norteiam e dirigem a educação de hoje.

Por fim, DURKHEIM apresenta a seguinte definição para a educação:

A educação é a ação exercida pelas gerações adultas sobre as gerações que não se encontrem ainda preparadas para a vida social; tem por objeto suscitar e desenvolver na criança certo número de estados físicos, intelectuais e morais, reclamados pela sociedade política, no seu conjunto, e pelo meio especial em que a criança particularmente se destine. (DURKHEIM, 1978, p. 38).

Então, de acordo com a definição de educação proposta por DURKHEIM (1978), podemos inferir que a função das ações

\footnotetext{
${ }^{4}$ Émile Durkheim. Educação e Sociedade, 1978.
}

educativas é transformar o ser individual em ser social, considerando as crenças e práticas religiosas e morais, as tradições e profissões da coletividade. Pensando a educação como atividade social, DURKHEIM (1978) não deixa de considerar o caráter econômico da educação, pois de acordo com ele a educação busca, também, atender aos interesses da economia interna para o equilíbrio da sociedade.

Dessa forma, a educação, desde a sua institucionalização, ocorre da seguinte maneira: formal, informal e não-formal, o que passaremos a discutir a seguir.

A educação formal dá-se através das instituições de ensino regidas por leis específicas. A educação informal refere-se ao processo educativo do meio socio-cultural e se realiza através de processos espontâneos e naturais provenientes do convívio social do ser humano, quer seja nas relações familiares, quer seja nas mais diversas atividades realizadas pelo homem. Já a educação nãoformal ocorre de maneira sistemática e organizada e tem por objetivo o desenvolvimento humano, quer seja profissional, quer seja pessoal.

Assim, levando em consideração o exposto acima podemos dizer que a educação é também algo que acontece ao longo da vida, o que, se podemos assim dizer, amplia a ideia de educação permanente, encarada nesta transição de milênio, não só com alterações da vida profissional, mas uma construção humana continuada. Pressupondo que a prática educativa seja histórica e que tenha 
historicidade podemos inferir que enquanto prática social, a prática educativa em sua riqueza e em sua complexidade é um fenômeno típico e exclusivo da existência humana.

\section{Um breve histórico da Informática na educação}

A história da tentativa da introdução da informática no processo ensinoaprendizagem foi marcada por tropeços, falhas e desistências.

Esta trajetória foi (e está sendo ainda) longa, mas consagrada por vários momentos que vale a pena relembrarmos, para que, com mais convicção e firmeza possamos nos alertar e hoje já com o conhecimento dos vários caminhos percorridos, não abandonalos, mas caminhar conscientes de que em vários trechos deveremos usar desvios, evitando os declives que causaram o insucesso da introdução de um processo que é fundamentalmente importante para a resistência ao adestramento intelectual.

De acordo com OLIVEIRA et al (2004), a temática relativa a informática na educação vem sendo bastante discutida e pesquisada na atualidade ancorada em paradigmas teórico e científicos bastante diversificados, o que tem gerado discussões bastante "calorosas" e acirradas acerca do assunto.

Ainda de acordo com referencial citado acima e remetendo-nos a MAGGIO $(1997)^{5}$ e SANCHO $(1998)^{6}$, podemos

5 MAGGIO, M.O. "O campo da teconologia educacional: algumas propostas para a sua identificar duas concepções: a primeira priorizada nas décadas de 60 e 70 do milênio passado, que alicerça-se nas teorias da comunicação e da aprendizagem e considera a tecnologia como uma ferramenta, ou seja, como um meio capaz de colaborar com o alcance da aprendizagem, acarretando redução do ensino ao aperfeiçoamento de materiais. Já a Segunda concepção, embasada na Teoria dos Sistemas, considera a tecnologia tanto como uma panacéia, no sentido de resolver problemas educacionais, quanto um recurso, deveras eficaz, na diminuição de custos e encargos financeiros.

$\mathrm{Na}$ área educacional, numa perspectiva internacional, os anos 80 promoveram a consolidação do emprego da informática nas escolas, sobretudo como ferramenta para a solução de problemas e manipulação de dados, o que incentivou a criação de novos ambientes de aprendizagem. No caso específico do Brasil, os documentos e discursos oficiais vêm legitimando o mencionado dispositivo: "a crescente e irresistível presença do computador, dos recursos da informática em geral, nos mais corriqueiros atos da vida das pessoas, tornou indispensável, como ação do governo, a informatização da escola pública" - MEC, 1997.

recontextualização", citado por OLIVEIRA et al (2004) “A informática na educaçao". In: Novas Linguagens e Novas Tecnologias: educação e sociabilidade.

${ }^{6}$ SANCHO, J.M. (org.) (1998). "Para Uma tecnologia educacional" , citado por OLIVEIRA et al (2004) "A informática na educaçao". In: Novas Linguagens e 177 
Dessa forma, as primeiras iniciativas no âmbito da informática educativa no Brasil, de acordo com OLIVEIRA (2004, p. 41) "são adotadas na década de 70 , quando se começa a discutir, com a assessoria da Universidade de Dartmouth, a importância do uso do computador no ensino de física e, assim, em 1973, realizou-se a $1^{\text {a }}$ Conferência de Tecnologia Aplicada ao Ensino Superior".

Apesar de ter sofrido influências dos modelos europeus e americanos a informática na educação no Brasil desenvolveu-se de forma própria. Dessa forma citaremos alguns acontecimentos que fizeram parte desta trajetória.

Um marco bastante considerável na história da informática na educação, no Brasil, deu-se na década de 80 , com a criação da Secretaria Especial de Informática (SEI), que tinha como objetivo traçar os rumos da educação na área da Tecnologia.

Em 1981, com a promoção da SEI, do Ministério da Educação e Conselho Nacional de Pesquisa (CNPq), aconteceu o I Seminário Nacional de Informática Educativa. Em 1982, na Bahia ocorre o II Seminário Nacional de Informática Educativa, quando percebeu-se que as conclusões a que se haviam chegado, tanto no I Seminário, quanto no segundo apontavam para a necessidade de formação de recursos humanos e à implementação de centros pilotos de informática.

Em 1984, esses centros foram consubstanciados no Projeto EDUCOM (Educação por computadores), implementado na Universidades Federais de Pernambuco,
Minas Gerais, Rio Grande do Norte, Rio de Janeiro e na Universidade Estadual de Campinas (Unicamp). O Educom se constitui como uma iniciativa pioneira do governo brasileiro na esfera da informática educativa.

Em 1986, foi criado o Comitê Assessor de Informática na Educação, que tinha como objetivos motivar o uso do recurso em questão, através do "Programa de Ação Imediata em Informática na Educação, no $1^{\circ} \mathrm{e}$ $2^{\circ}$ graus", e promover a avaliação do Educom.

Em 1989, foi criado o Programa Nacional de Informática na Educação (o Proninfe), que determinava a implantação de núcleos de tecnologia nas diferentes regiões brasileiras com o propósito tanto de capacitar professores da rede pública para o emprego da informática educativa, quanto de desenvolver metodologias, processos e sistemas. Simultaneamente, foi implementado o Projeto FORMAR, vinculado ao Educom, da Unicamp, que deveria se tornar responsável pela capacitação de docentes, nos recémcriados Centros de Informática Educativa (Cieds), através de cursos de especialização.

Em 1990, o Educom é extinto. Em 1997, o Ministério da Educação elabora o Programa Nacional de Informática na Educação (o Proinfo.

Quando a informática a informática deixou de ser apenas assunto de revista especializada, a (BBS BULLETIM BORD SYSTEM, uma espécie de provedor popular anterior à disseminação da Internet), já era utilizada por grande parte da população. 
Sendo assim a informática que só era utilizada praticamente por usuários interessados apenas nos serviços que a Internet poderia oferecer, começa ser alvo de empresas (1997 a 1999) que a viam como alvo de facilidade e agilidade para seus negócios.

Já nestes dois últimos anos cresce o interesse pela Educação à distância e como ferramenta de apoio a Internet que desperta na educação formal o interesse pela ferramenta que aparentemente traria facilidade para alguns e constragimento para outros. Os professores se viram "obrigada" a aprofundar no novo método para não se sentirem obsoletos dentro da prática já totalmente conhecida e segura para eles. A resistência à incorporação da informática como método de ensino começa a florescer.

Lucena atribui a resistência dos profissionais em incorporar as novas tecnologias às histórias das tentativas de implantação de informática nas atividades das escolas.

\section{Vamos à cronologia:}

- Final da década de 60 - Tecnologia Educacional - tentou-se levar a escola à um funcionamento racional de formação de mão de obra;

- Acordo MEC-Usaid - política de privatização da educação (deram origem as grandes manifestações estudantis de 1968 - supervalozização da tecnologia educacional - Tecnicismo Educacional - acredita-se que seria a solução para os problemas da educação brasileira;

- 1980 - Revalorização do uso das tecnologias educacionais (iniciativa dos altos escalões do governo brasileiro, como em 60);

- Criação da Comissão Especial de Educação com o objetivo de criar novas normas e diretrizes para a área de informação;

- 1981 e 1982 - I e II Seminário Nacional de Informática na Educação pela $1^{\circ}$ vez reuniu-se pessoas diretamente ligadas ao processo educacional;

- 1983 - EDUCOM - Educação com computação: encerrado por falta de continuidade de recursos, mas criaram condições para dois outros projetos FORMAR (Visava a preparação de professores e técnicos das redes municipais e estaduais de ensino) e CIED ( Centro de Informática e Educação).

- 1987 - Descentralização do MEC para as secretarias municipais e estaduais - houve descontinuidade devido ao despreparo das equipes, ausência de discussão e participação mais ampla de professores e estudantes, falta de infra-estrutura, obsolência rápida da informática e de manutenção.

Assim, foram citados acima fatos ocorridos na trajetória da tentativa de implantação, mas verdadeiramente existia um problema maior: A confusão entre utilizar a 
informática na prática educativa e ensinar a informática

Fixadas neste problema que certamente contribuiu para inúmeros fracassos na proposta da integração da informática aos conteúdos disciplinares é que resolvemos nos aprofundar na questão da formação dos professores.

A temática do trabalho é averiguar se os professores se encontram preparados para atuarem nessa nova realidade informatizada, senão, como e quais recursos poderão auxiliar para prepará-lo frente às tecnologias no processo de ensino-aprendizagem.

\section{O PROINFO - Legislação}

De acordo com informação retirada do site do MEC, o Programa Nacional de Tecnologia Educacional (ProInfo) é um programa educacional criado pela Portaria $\mathrm{n}^{\mathrm{o}}$ 522, de 9 de abril de 1997, pelo Ministério da Educação, para promover o uso pedagógico da informática na rede pública de ensino fundamental e médio.

O ProInfo é desenvolvido pela Secretaria de Educação a Distância (SEED), por meio do Departamento de Infra-Estrutura Tecnológica (DITEC), em parceria com as Secretarias de Educação Estaduais e Municipais.

O programa funciona de forma descentralizada, sendo que em cada Unidade da Federação existe uma Coordenação Estadual do ProInfo, cuja atribuição principal é a de introduzir o uso das tecnologias de informação e comunicação nas escolas da rede pública, além de articular as atividades desenvolvidas sob sua jurisdição, em especial as ações dos Núcleos de Tecnologia Educacional (NTEs).

A adesão das escolas e a conseqüente implantação do Projeto, ou seja, dos laboratórios de informática, de acordo com as diretrizes do PROINFO, estão condicionadas à apresentação, por parte das mesmas, de um projeto que contemple características pedagógicas e estruturais, ou ainda nas palavras de OLIVEIRA, et al (2004:45) à elaboração de um projeto pedagógico que incorpore, efetivamente, o uso da informática educativa na instituição.

\section{Perfil tecnológico do professor dentro do processo de aprendizagem}

A natural evolução do processo de informatização da sociedade provocou várias transformações no nosso cotidiano, e seria totalmente utópico pensar que estas transformações não atingissem cunhos pedagógicos.

O uso das novas tecnologias na educação representa um grande paradoxo. Se por um lado existe uma diversidade de ferramentas de trabalho, cada vez mais sofisticadas que permitem desenvolver aulas bem elaboradas, interativas, com boa forma, por outro constata-se que a prática na escola em relação ao uso das novas tecnologias não ocorre através de metodologias adequadas, muitas vezes não tem sido se quer uma preocupação a introdução as novas 
tecnologias no processo ensinoaprendizagem. Essa situação coloca os professores diante de novos desafios, o que exige para novas mudanças no campo pedagógico através do repensar da estrutura metodológica e a prática pedagógica. Segundo MOREIRA(1986):

O processo de informatização da
Educação deve ser considerado como
meio de ampliação das funções do
professor, favorecendo mudanças nas
condições e no processo de ensino
aprendizagem e não como meio de
substituição da ação do docente.
(MOREIRA, 1986, p. 2).

Nessa perspectiva deve-se repensar o papel do professor diante e para o uso das novas tecnologias, uma vez que, exige-se que o professor esteja sempre se aprimorando, pois a aprendizagem faz parte de um processo continuo e inacabado. Trata-se de "aprender e reaprender" e talvez o mais importante, seja aprender junto com o aluno, considerando que as experiências vivenciadas por eles possam sintetizar as novas ideias surgidas em meio a interação, principalmente quando se apoia no processo de ensino-aprendizagem com o auxilio das ferramentas de informáticas. Como consequência o professor é visto como um mediador do processo, o que torna um desafio exigir que ele assuma um papel de estimulador do conhecimento, ativo, reflexivo e criativo.

Diante disso, o papel atribuído ao professor é de motivador, coordenando o processo de construção de conhecimento, uma vez que, não assume a condição de dono do saber, mas de mediador do conhecimento respeitando o ritmo de cada aluno participante do processo ensino-aprendizagem, não impondo, mas sim acompanhando e atuando quando se fizer necessário através de intervenções que permitam promover a cooperação, o conflito e a socialização de ideias dentro dos ambientes inteligentes de aprendizagem.

Outro aspecto importante nessa interação é a de que o professor ao incentivar o aluno desperte a necessidade de buscar conhecimentos fazendo com que ele aprenda a aprender com autonomia.

Ensinar utilizando como ferramenta auxiliar o "computador e seus utilitários", não é uma tarefa fácil, porque exige uma forte dose de atenção do professor, diante da interação professor - computador - aluno. $\mathrm{Na}$ troca de conhecimentos podem surgir inúmeras possibilidades a serem aprimoradas e questionadas, isto fará com que o professor assuma um papel flexível para tratar dos assuntos que permeiam a educação.

Assim sendo, DERTOUZOS(1995, p.

2) explicita que "Está nas mãos dos professores a busca de uma nova mentalidade pedagógica. E para isso ele precisa aprender como usar as novas ferramentas para atingir metas mais ambiciosas em termos de conhecimentos."

Ao observarmos o impacto proporcionado pela tecnologia em nosso cotidiano perceberemos a real necessidade do redimensionamento do papel do professor, na junção do seu conhecimento específico as 
novas tecnologias. Esta interação resultará na evolução e aprimoramento dos conhecimentos e informações.

Sendo assim, o professor tem hoje a função especifica de mediar e colaborar com as trocas de informações considerando as características individuais do aprendiz perante todo o processo, o que requerer uma profunda análise das estratégias e recursos a serem utilizados diante do processo de ensinoaprendizagem.

Percebe-se então que um professor deve ser um bom planejador, mas sem deixar de lado a flexibilidade, um articulador do conhecimento, um estimulador, ou seja, estar aberto às contribuições feitas pelos alunos, uma vez que eles assumem papéis importantes no conteúdo do processo, proporcionando ao ensino uma troca constante de informações e por fim ter um domínio dos seus conteúdos disciplinares e dos conhecimentos paralelos, quer dizer, dos teóricos e de seus instrumentos de auxilio, como no caso deste estudo a informática e seus recursos são direcionados como meio utilizado para apoiar o processo pedagógico na implementação do ensino. Assim afirma VALENTE (1993, p.3) “... computador na educação não significa aprender sobre computadores, mas sim através de computadores."

Por isso, deve-se repensar o ensino com a utilização das novas ferramentas dentro de linhas construtivistas deixando de lado a ideia de que se deve imaginar o processo de conhecimento como algo pronto, que há permanente necessidade de se explorar as ideias na perspectiva de atuação e articulação ativa dos alunos.

Portanto parte-se do principio de que o professor seja um "elemento inacabado" diante do seu preparo para o ensino assumindo uma responsabilidade de que deve estar sempre se atualizando em relação a sua disciplina e as ferramentas que o auxiliam de forma eficaz para o ensino suprindo as exigências que apoiam o mercado educacional.

\section{A importância do computador e seus utilitários como um recurso didático}

Apoiados pelas exigências das novas tecnologias, percebemos que a necessidade de integrar os novos recursos como instrumentos auxiliares para a educação proporcionará aos professores e alunos maiores possibilidades de recursos para se conduzir o processo de ensino-aprendizagem. Tem sido notória a revolução causada pelos computadores integrados a educação, uma vez que vem se destacando pela possibilidade de se ensinar utilizando esse recurso como instrumento de promover uma melhor interação, mediante trocas de informações. De acordo com MOREIRA (1986, p. 8) o uso da informática no processo de ensino aprendizagem deve basear-se "...no principio de que o ensino pelo computador ocorra mediante trocas funcionais entre o sujeito e o objeto da aprendizagem..."

Dentro dessa perspectiva apontar-se-á para a nova realidade vivida nos contextos 
escolares dos alunos, levando-se em consideração a educação como um dos seus pivores. Hoje suas atividades vem sendo amparadas pela utilização do computador como um dos principais meios de comunicação e troca de informações. Baseado nas diversas abordagens que permeiam a educação e estratégias de ensino estaremos apontando caminhos para a evolução e as descobertas de como construir o processo pedagógico, deve-se por assim dizer que estaremos destacando o computador e alguns de seus principais utilitários para uso na educação.

Segundo MERCADO (1999):

(...) as escolas que utilizam estas tecnologias no processo de ensino aprendizagem necessitam ter um projeto político-pedagógico, em que os profissionais competentes e criativos sempre estejam repensando a sua prática pedagógica e acompanhando a tecnologia educacional, visando assim uma formação do sujeito crítico e ajudando na construção do seu educando. (MERCADO, 1999, p. 19).

Como pode ser percebido o uso da informática já se tornou uma realidade no processo de ensino-aprendizagem, assim sendo, vem desenvolvendo suas atividades em prol as novas estratégias para se construir uma pedagogia capaz de integrar a educação e a informática.

Abordar-se-á a seguir meios capazes de prover a interação nos ambientes de aprendizagem, na qual poderão haver as inúmeras trocas de informações, seja através de e-mails, salas de bate-papo (chat) para conversas on-line ou mesmo através de lista de discussões em grupo sobre determinados assuntos, sem contar os jogos interativos que possibilitarão as competições em que os alunos vivenciam situações de aprendizagem, mas é claro que tudo isso deve ser acompanhado pelo mediador do conhecimento que neste caso será o professor e seu objetivos pedagógicos. Outro recurso importante é o de apresentação: o power point, utilizado para elaborações de apresentações de conteúdos, tarefas e trabalhos a serem compartilhados e por suas vez os vídeos, sons e imagens gráficas. Mas deve ficar claro que o fato de se utilizar todos os recursos citados não se determina uma pedagogia eficaz no sucesso da aprendizagem ou seja apenas trocaríamos o quadro negro pelo computador.

Destacar-se-á também os recursos de pesquisa como as bibliotecas virtuais e os dispositivos de armazenamento de informação como o CDROM e DVD. É interessante observar as facilidades apresentadas atualmente quando se busca pesquisar sobre qualquer assunto, como por exemplo os sites que trazem bibliotecas on-line, venda de livros e revistas acompanhados de CDROM sem precisar sair de casa, para se adquirir qualquer titulo de que esteja precisando. Mas tudo isso, ainda assim exige-se que o professor esteja atento para uma seleção prévia da busca que seus alunos farão ou seja o direcionamento dos sites a serem 
poderá se criar também um foco de dispersão nas consultas de sites impróprios a aprendizagem.

Contar-se-á também com os recursos auxiliares como os editores de texto, planilhas eletrônicas, recursos gráficos (desenhos, sons e animação), banco de dados dentre outros que facilitarão aos professores e alunos o desenvolvimento de suas atividades, favorecendo assim a motivação e a estimulação no processo ensinoaprendizagem.

Outro recurso importante é o de se utilizar softwares educativos para o trabalhos com conteúdos específicos, lembrando que o professor deverá ser capaz de avaliar o conteúdo do recurso, ou seja, pontuar o grau de precisão que estes meios têm para atender e contribuir para a aprendizagem. Além disto, através de softwares educativos do tipo simulação, serão capazes de possibilitar aos alunos experimentos impossíveis de serem percebidos na prática. Temos ainda a habilidade da programação em LOGO que leva os alunos a criação de uma autonomia sobre seus trabalhos, sendo capaz de provocar sua imaginação e a preocupação em superar suas dificuldades, motivando-os a recriação de estratégias, uma vez que os erros contribuem efetivamente para o processo de aprendizagem. VALENTE afirma que: “ $\mathrm{O}$ computador, como ferramenta, é capaz de tratar o erro (uma dúvida) como propulsor de desafios e, consequentemente aprimorador do processo de ensino-aprendizagem.”
Por isso exige-se também que o professor esteja sempre atento para ser capaz de promover uma atitude mediadora intervindo quando necessário diante de seus desafios na superação das dificuldades apresentadas no processo de aprendizagem.

Abordar-se-á a modalidade que mais vem se destacando nos últimos anos dessa trajetória, o Ensino a distância, que possibilita a aprendizagem estando em diversos pontos do mundo através da conexão em rede, embora uma prática antiga, só agora vem sendo utilizada com maior frequência, o que acreditamos ser pelo fato de que o computador vem se tornando mais acessível em residências e sem contar com o fim da resistência da utilização da máquina, ampliando assim a utilização desse recurso. Percebemos que o uso da informática na educação contribuiu para três contextos: o primeiro como recurso de comunicação, o segundo como suporte para projetos educativos e o terceiro como fator para novos processos de ensino/aprendizagem.

Cabe então salientar que apontamos acima apenas algumas das inúmeras possibilidades de interação que o professor pode promover através dos recursos tecnológicos dentro da "sala de aula" para o desenvolvimento da aprendizagem.

Contudo, deve-se ficar claro que o fato de se utilizar os recursos tecnológicos não garante o sucesso no processo do ensinoaprendizagem, pois o mais importante é que o mediador esteja preparado para integrar os recursos a uma pedagogia eficaz, capaz de 
promover a reestruturação dos esquemas existentes nos alunos.

\section{O processo de aprendizagem}

Mediante às inúmeras mudanças ocorridas no processo de ensinoaprendizagem tendo em vista como principal colaboradora o uso das novas tecnologias, devemos então levar em conta todo os valores culturais, sócio-políticos e pedagógicos da realidade dos alunos.

Trata-se então de uma nova cultura para o aprendizado, o que nos faz refletir sobre a posição do professor bem como um meio para ampliar suas funções e conhecimentos, apropriando da ferramenta como uma forma de descobrir possibilidades para se próprio e para a aprendizagem do aluno. É importante lembra que o uso da informática como ferramenta de auxilio para o ensino não garante o "sucesso" na aprendizagem, mas sim com que objetivo iremos usá-la, o que nos faz perceber a importância dos professores apropriar-se criticamente e assim repensar o próprio ato de ensinar de formar aproximar-se da realidade de seus alunos.

Sabemos que não basta somente adotar técnicas modernas para o ensino, mas prepará-las mediante fundamentos psicopedagógicos que direcionem a uma certa concepção de ensino e aprendizagem.

\section{Concepções de aprendizagem}

Visão empirista - Todo conhecimento provém da experiência.
Em virtude dos pensadores como Skiner, Pavlov entre outros que direcionam o conhecimento como proveniente somente do objeto desconsiderando toda e qualquer contribuição do sujeito, na qual o conhecimento se forma a partir de registro dos fatos. Nesta perspectiva teremos uma visão Behaviorista em que a psicologia se define como a Ciência do comportamento, ou seja seu conhecimento se dá através de conjunto de reações medidas e previstas e ate mesmo controladas que se dá perante o condicionamento.

Estes resultam-se em uma associação de estímulos e respostas que como consequência obedecem a princípios mecânicos. Pressupõe- se então que este tipo de visão determina o ambiente como um fator primordial para o desenvolvimento da aprendizagem, outro é o de que o comportamento humano deve ser compreendido como estímulo e resposta condicionando ou modificando o comportamento do aluno e por ultimo a ideia de que se é possível medi-lo.

Definimos então que o professor passa a ser um manipulador das condições ambientais dos alunos assegurando assim a aprendizagem e enquanto o aluno o de receptor de conhecimentos resultando em associação de estímulos e resposta.

Visão racionalista - Todo conhecimento é anterior à experiência, uma vez que o sujeito já possui conhecimento sobre o objeto. 
Ao contrario do empirismo a teoria de Gestalt propõe que todo o conhecimento já são estruturas racionais pré-formadas no sujeito desde o seu nascimento, ou seja, rejeita a ideia de que o conhecimento possa vir das experiências. Segundo MOREIRA (1986:p.5) afirma que: "As "Gestaltens" (configurações) são as legitimas unidades mentais, inerentes à razão humana, e é para elas que a Psicologia deve voltar-se." Assim a explicação para a aprendizagem dentre alguns dos pensadores Gestaltistas (Koffka, Kohler e Lewin) é de que ela se reduz a solução de problemas ou a insights (compreensão imediata baseado na percepção).

Visão construtivista - Todo o conhecimento é resultante da relação entre sujeito $\mathrm{X}$ objeto em que ambos contribuem no processo de aprendizagem.

Nesta talvez uma das mais importantes visões, parte do principio de que para existir a aprendizagem deve haver entre o sujeito e o objeto uma interação, ou seja contribuem a todo momento para que hajam reconstruções de seus esquemas já formados resultando em novas estruturas. Afirma MOREIRA (1986, p. 6) “...a aprendizagem é sempre resultante da relação sujeito/objeto, relação essa onde os dois termos não se opõem, mas se solidarizam, formando um todo único."

A concepção construtivista tem como um dos seus principais estudiosos Jean Piaget, Wallon, Vigotsky e outros.

Na perspectiva de Piaget o sujeito e o meio se fundem tornando uma totalidade favorecendo a um possível desequilíbrio fazendo com que ele se esforce para adaptar e se restabelecer ou seja para que ambos passem por uma assimilação e a acomodação.

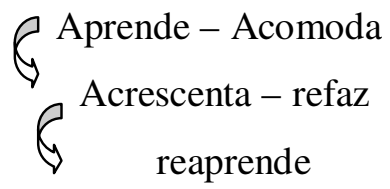

Assimilação cognitiva é o momento em que o sujeito se apropria de elemento exterior as suas estruturas integrando esse novo conhecimento ao seus esquemas já formados para amplia-los, sendo assim temos a ação do sujeito sobre o objeto. Já na acomodação é o que chamamos da ação do objeto sobre o sujeito. Piaget afirma que para uma "equilibração" deva haver uma acomodação das estruturas e em paralelo o que ele chama de organização, ou seja a medida em que o sujeito assimila e acomoda dão origem a uma integração surgindo uma subestrutura.

Neste sentido é que a concepção construtivista tem se destacado mediante o ensino pelo computador em que deve ocorrer através das trocas entre o sujeito e o objeto da aprendizagem estimulando o sujeito contribuir com suas estruturas cognitivas já existentes e também a possibilidade de construção de novas estruturas, mais precisamente à medida em que o aluno é capaz de utilizar o computador para a realização de seus trabalho e como consequência assimilar e acomodar o conteúdo proposto pela disciplina. 
Enfatiza-se portanto, que quando o professor decidir se apropriar desta ferramenta (computador) como um auxilio para o aluno em seus conteúdos didáticos, ele deve levar em conta as características individuais de cada sujeito assim como seu contexto, estar preparado para as intervenções à medida em que se fizerem necessárias na aprendizagem do aluno, procurar optar por trabalhos em grupos que estimulem uma discussão (troca de ideias) na superação das dificuldades e até mesmo conceber um crescimento cognitivo colaborando para o desenvolvimento intelectual de cada aluno. Sendo assim é importante que o professor não se limite em fazer previsões de ações, uma vez que aos alunos serão fornecidos conhecimentos estimulando uma autonomia para buscar novas fontes de conhecimento.

Entende-se então que para propor a formação de professores capazes de integrar as novas ferramentas a um processo de aprendizagem eficaz, ele deve, antes de mais nada, identificar uma concepção teórica coerente, ou seja, se por um lado a concepção behaviorista ainda seja predominante nos contextos escolares e ainda assim tem sido utilizada inadequadamente de acordo com algumas das necessidades, vejamos a concepção construtivista que tem se mostrado uma alternativa diante e para auxilia-lo dentro das novas perspectivas da aprendizagem exigidas pela sociedade.

Trata-se então de exigências que hoje permeiam a formação do professor para o uso das novas tecnologias, ou ainda, são exigências capazes atender as demandas da sociedade, considerar as expectativas e potencial dos alunos, criar uma autonomia entre ambos (professor $\mathrm{x}$ aluno) para que esses possam desenvolver uma aprendizagem de forma cooperativa, estimular a tomada de decisões e acima de tudo estarem preparados para reconstruir seus conhecimentos, contudo incorporar as novas tecnologia não somente para expandir o acesso as fontes de informação, mas a criação de ambientes ricos que contribuam para a construção do conhecimento.

Portanto, o que se busca é uma concepção que possa atender aos diversos momentos da aprendizagem tanto de um professor quanto de aluno.

\section{Porque integrar a informática ao ensino escolar?}

Atender hoje as necessidades da educação é um assunto um tanto quanto complexo em se tratando do uso da informática como instrumento de ensinoaprendizagem. Pode-se perceber uma grande ansiedade quando se fala em estar preparado para usá-la como instrumento de ensino, uma vez que se quebra todos os paradigmas já existentes do processo de ensinoaprendizagem, lembrando que não se espera o sucesso e a eficácia pelo simples fato de estar usando o recurso, mas de como usá-lo para promover a aprendizagem.

Quando se relaciona o uso da informática, como recurso pedagógico, ao 
aumento da eficiência e na qualidade do ensino, deve-se, antes de mais nada, ser realista com relação à situação atual da educação e, consequentemente, à realidade vivida por nossos alunos e professores e atentar-se para que o simples fato de utilizar a informática como ferramenta de ensino não fará com que todos os problemas, já conhecidos, sejam solucionados ou até mesmo que os alunos instantaneamente tenham sua inteligência expandida, ou mesmo que sua auto-suficiência atinja um nível tão elevado que dispense a ajuda do professor.

Segundo MORAN (2000):

Um dos grandes desafios para o educador é ajudar a tornar a informação significativa, a escolher as informações verdadeiramente importantes entre tantas possibilidades, a compreendê-las de forma cada vez mais abrangente $\mathrm{e}$ profunda e a torná-las parte do nosso referencial. (MORAN, 2000, p. 23).

Tendo em mente a ideia de que se deve explorar bem o imenso potencial das tecnologias, nos deparamos com algumas das possíveis contribuições como uma forma de estímulo para o desenvolvimento intelectual de suas habilidades criando maior interesse, por parte dos alunos, em aprender e uma busca incessante por mais e novas informações tratando a aprendizagem como um processo contínuo, promovendo uma cooperação entre si e uma maior interação entre professor e aluno.

É interessante lembrar que os recursos tecnológicos, quando bem utilizados, trazem inúmeras informações e ferramentas que contribuem para a construção do conhecimento, mas cabe ao professor saber explorar nelas a sua eficiência para o sucesso da aprendizagem, sendo importante salientar a ideia de que o professor deve planejar a aplicação destes recursos, procurando antes da sua utilização identificar a melhor maneira de inseri-lo na prática educativa de forma que se tenha respostas (ou melhoramentos) para os problemas da educação.

Existem várias maneiras de utilizar o computador na educação, uma delas é informatizando os métodos tradicionais de instrução. $\mathrm{O}$ computador enriquece ambientes de aprendizagem, fazendo com que o aluno interaja com os objetos desse ambiente, criando possibilidades para construção do seu conhecimento. Podemos citar várias possibilidades (hipertextos, multimídias, experimentos, simulações, etc) e caminhos que o computador nos propicia para integração da informática ao ensino escolar.

Afirma MORAN (2000, p. 23) "aprendemos mais quando estabelecemos pontes entre a reflexão e a ação, entre a experiência e a conceituação, entre a teoria e a prática; quando ambas se alimentam mutuamente."

A utilização adequada desses recursos faz com que se deixe de lado toda uma formação empirista que, comprovadamente, não leva à reflexão, crescimento intelectual e intuitivo e sim ao adestramento intelectual podando nossos alunos da socialização do conhecimento e formação para uma cidadania 
consciente, ativa e crítica. Só assim poderemos vislumbrar e tornar possível uma transformação em nível pessoal, social e educacional.

\section{Cultura do ciberespaço}

“(...) todas as mensagens se tornam interativas, ganham uma plasticidade e têm uma possibilidade de metamorfose imediata".(LEVY, 2003, p. 13).

\section{A rede mundial}

A Internet pode ser entendida como uma vasta rede internacional composta de cerca de 150.000 redes de computadores individuais e milhões de usuários individuais espalhados por todo o mundo.

É muito difícil mensurar a dimensão da Internet, porque não há um ponto central de controle e porque a Rede cresce em uma taxa quase exponencial. Segundo a E-conulting, só o Brasil possui 25 milhões de internautas. E de acordo com pesquisas do Ibope/NetRating, os brasileiros ficaram em julho do ano passado 2004), em média, cerca de $16 \mathrm{~h}$ e $54 \mathrm{~min}$ conectados, ou seja, somos a população que passa mais tempo na internet no mundo.

Unida através de uma linguagem comum ou protocolo, a Internet permite aos usuários individuais que interajam, a seu modo, com qualquer outra rede ou usuário individual que seja também parte do sistema. Ou seja, a Internet é uma rede de computadores que fala a mesma língua, o protocolo IP. Desde o começo foi vista como anárquica exatamente porque não tem a estrutura hierárquica de uma pirâmide, um organograma vertical, e cresce horizontalmente, sem comando central.

As mensagens e comandos são transformadas, em seu ponto de origem, em pacotes de informações, cada qual com seu próprio endereço e instruções de destino, e assim transmitidas através de redes interligadas, para serem remontados no destinatário. Computadores especializados mandam cada pacote progressivamente, selecionando o caminho menos congestionado.

Pacotes compondo uma comunicação única frequentemente seguem caminhos muito diferentes, atravessando muitas redes de computadores e sendo conduzidos adiante em cada local por qual trafega. No destino, outro computador irá remontar a mensagem, seguindo as informações contidas nessa mesma mensagem.

$\mathrm{O}$ acesso à Internet é concretizado geralmente através de Provedores de Acesso à Internet, muito embora muitas empresas já possuam acesso próprio e independente.

A Internet e sua aplicação mais proeminente, a World Wide Web (ou WWW), são por sua natureza, desprovidos de limites territoriais tradicionais. Muito embora cada participante da Internet tenha seu próprio "endereço", nem sempre o destinatário fica sabendo da localização física do remetente.

Muitos usuários poderão acessar suas contas de Internet virtualmente de qualquer lugar no mundo através de satélites, dispositivos sem fio. Uma vez que na "Net" 
eles podem enviar e receber e-mails, navegar e conduzir negócios.

\section{Ciberespaço}

Ciberespaço é o ambiente criado de forma virtual através do uso dos meios de comunicação modernos, destacando-se entre eles a Internet. Esse fenômeno se deve ao fato de, nos meios de comunicação modernos, haver a possibilidade de pessoas e equipamentos trocarem informações das mais variadas formas sem preocupações. Também conhecido como Cyberespaço, um termo muito comum na ficção científica o qual dar variações para vários outras denominações referente à Internet, como Cybersex, Cyberpoeta, Cyberpunk e outros mais. A palavra "cyberespaço" (uma junção de cibernético com espaço) foi projetada por um escritor canadense de ficção científica Willian Gibson, em 1984 no seu livro "Neuromancer". Pierre Lévy coloca o ciberespaço como uma grande rede interconectada mundialmente, com um processo de comunicação "universal" sem "totalidade". A "universalidade" sem "totalidade" segue uma linha interativa de comunicação, possibilitando a "todos" navegantes da grande "rede" participarem democraticamente num modelo interativo de "todos para todos", consolidando a ideia de uma "aldeia global" profetizada por Mcluhan na década de 60. O ciberespaço dissemina uma nova cultura pelo globo a cibercultura.

\section{Cibercultura}

A cibercultura é um termo utilizado na definição dos agenciamentos sociais das comunidades no espaço eletrônico virtual. Estas comunidades, Msn, Chats, Orkut, Blogs e Icqs, estão ampliando e popularizando a utilização da Internet e outras tecnologias de comunicação, possibilitando assim maior aproximação entre as pessoas de todo o mundo. Este termo se relaciona diretamente com à dinâmica Política, Antropo-social, Econômica e Filosófica dos indivíduos conectados em rede, bem como a tentativa de englobar os desdobramentos que este comportamento requisita.

A Cibercultura provém de um espaço de comunicação mais flexível que o produzido nas mídias convencionais [TV, Rádio, Jornal]. Nas mídias convencionais o sistema hierárquico de produção e distribuição da informação seguem um modelo pouco flexivel baseado no modelo um-todos. Já no ciberespaço a relação com o outro se desdobra no contexto do todos-todos, nesse sentido, este ambiente comunicacional emerge com a potência que comporta o discurso democrático em sua gênese, uma maneira interativa de estar contribuindo, com novos conceitos e postulados.

\section{APRESENTAÇÃO E ANÁLISE DOS RESULTADOS}

\section{ANÁLISE DOS RESULTADOS DOS QUESTIONÁRIOS APLICADOS AOS PROFESSORES}


Neste item do artigo pretende-se

apresentar e analisar os resultados obtidos nas entrevistas feitas com professores e pedagogos da escola estadual em estudo.

Alguns resultados, aqueles que permitem tal formatação, serão apresentados a partir de gráficos.

Cabe reiterar que a primeira questão do questionário era referente a identificação do entrevistado e que os campos idade e nome eram opcionais, portanto não se consegue definir a porcentagem de homens e mulheres.

Ainda com relação aos entrevistados, pode-se perceber que eles vem das mais diversas áreas de formação. São professores de história, geografia, letras - português ciências, matemática, educação religiosa, educação física, dentre outros e que tem, em média, 06 anos de formados.

Na segunda pergunta do questionário, quando perguntados se conheciam o laboratório de informática da escola, a grande maioria afirmou conhecer, $87 \%$. O que causa certa estranheza é o fato de um grupo de professores não conhecerem o ambiente, $13 \%$, sendo que esse ambiente faz parte da estrutura física da escola em que trabalham.

\section{GÁFICO I}

VOCÊ CONHECE O LABORATÓRIO DE INFORMÁTICA DA SUA ESCOLA?

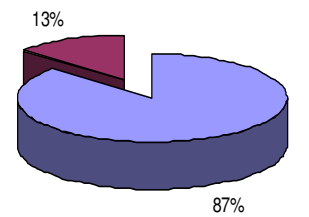

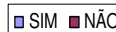

Outro ponto enfatizado na entrevista foi o momento de implantação do laboratório de informática na escola. Perguntou-se aos entrevistados se eles trabalhavam na escola no momento dessa implantação. $67 \%$ dos entrevistados afirmaram não trabalhar ainda na escola contra $13 \%$. Tal fato é perfeitamente normal, quando se leva em consideração a situação de um professor de escola pública estadual, quando esse não passou por concurso ou tem sua efetivação no cargo que exerce. É muito comum que esses profissionais não concursados e/ou não efetivados tenham permanência curta nas escolas em que trabalham.

\section{GRÁFICO II}

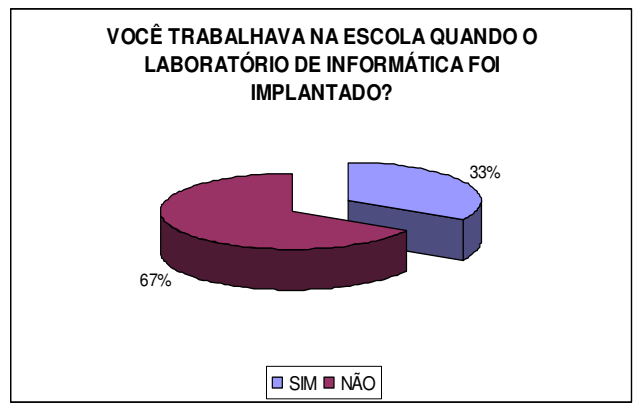

Fonte: Questionário aplicado

A questão quatro perguntava aos entrevistados se eles já haviam feito algum tipo de curso específico para manusear o computador. Dos entrevistados, $66 \%$ afirmaram já ter feito algum curso de informática; $27 \%$ não fizeram nenhum tipo de curso e $7 \%$ preferiram não responder. Dessa forma, percebe-se que o manuseio da máquina é competência de mais de $60 \%$ dos entrevistados, o que em tempos de globalização e evolução tecnológica é 
perfeitamente esperado, mas ao mesmo tempo um número ainda um pouco baixo quando levamos em consideração o tempo médio em que esses entrevistados se formaram.

\section{GRÁFICO III}

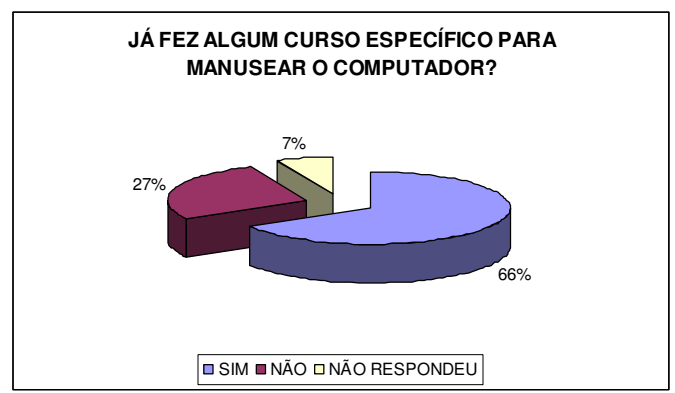

Fonte: Questionário aplicado

Logo após a questão anterior, perguntou-se aos entrevistados, mesmo não tendo feito qualquer tipo de curso de informática, se eles sabiam utilizar o computador. Pôde-se perceber com o resultado obtido que fazer um curso de computação não é pré-requisito para trabalhar com o computador. Dos entrevistados, $86 \%$ afirmaram saber utilizar o computador para algum fim, seja para digitação de textos, planilhas, apresentações, ou outro tipo de atividade, enquanto $7 \%$ afirmaram não saber utilizar a máquina e outros $7 \%$ preferiram não responder a questão.

\section{GRÁFICO IV}

VOCÊ SABE UTILIZAR O COMPUTADOR?

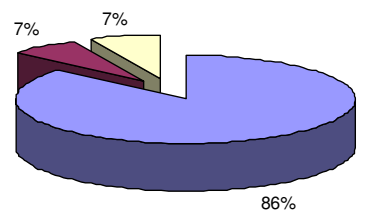

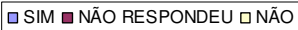

Fonte: Questionário aplicado
Outra pergunta feita foi sobre a INTERNET. Perguntou-se aos entrevistados se eles utilizavam a INTERNET. $80 \%$ responderam que $\operatorname{sim} .7 \%$ preferiram não responder e os outros $13 \%$ afirmaram não acessar a INTERNET, o que pode ser percebido no gráfico apresentado a seguir.

\section{GRÁFICO V}

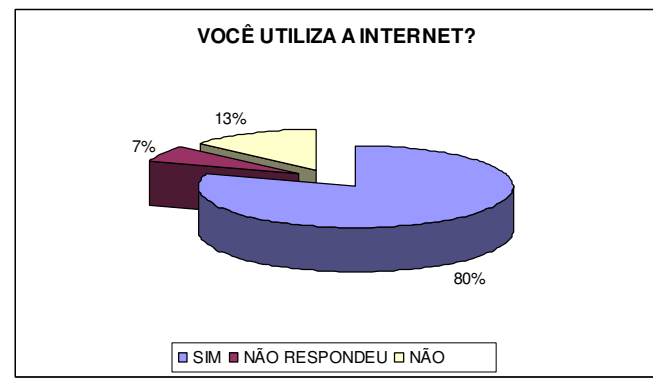

Fonte: Questionário aplicado

Ainda com relação ao uso da INTERNET, perguntou-se aos entrevistados com que finalidade eles utilizavam a rede mundial e as respostas foram as seguintes: Todos os entrevistados que utilizam a INTERNET, utilizam com mais de uma finalidade, seja para pesquisas pessoais, pesquisas para a sala de aula, demonstração em sala de aula e até para buscar novos relacionamentos.

Com relação à frequência com que eles utilizam a INTERNET, constatou-se que: $40 \%$ acessam a INTERNET uma vez por semana; $20 \%$ de duas a três vezes por semana; outros $20 \%$ de três a quatro vezes por semana; $7 \%$ mais de quatro vezes por semana e $13 \%$ preferiram não responder. 


\section{GRÁFICO VI}

EM MÉDIA, QUANTAS VEZES POR SEMANA VOCÊ UTILIZA A INTERNET?

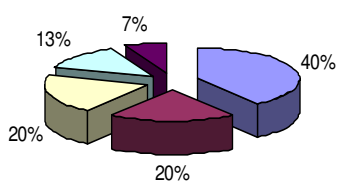

$\square$ UMA VEZ PORSEMANA $\quad$ DE DUAS A TRÉS VEZES POR SEMANA $\square$ DE TRÊS A QUA TRO VEZES POR SEMANA ם NÃO RESPONDEU

- MAIS DE QUATRO VEES POR SEMANA

Fonte: Questionário aplicado

Perguntou-se ainda aos entrevistados, se em algum tempo já haviam utilizado o laboratório de informática da escola. Constatou-se que mais de $60 \%$ já haviam utilizado o laboratório para alguma finalidade e grande parte com a finalidade de fazer pesquisas em sites de busca como o Google, por exemplo. Dessa forma, o que podemos perceber é que o laboratório de informática da escola é subutilizado, ou utilizado para fins não muito didáticos.

\section{GRÁFICO VII}

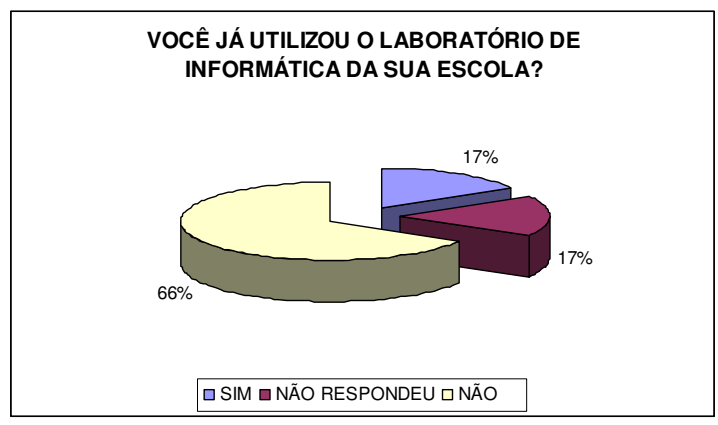

Fonte: Questionário aplicado

A décima segunda pergunta feita aos entrevistados trazia como subsídio uma informação veiculada pelos mais diversos tipos de mídias. Informamos aos nossos entrevistados, a partir de fontes seguras e reais, que se havia feito a seguinte constatação: Informática na educação - tema tratado com muita veemência e que tem revelado que os alunos têm se tornado mais criativos, interessados e comprometidos quando essa nova tecnologia está inserida no contexto escolar. Assim, a partir do exposto perguntou-se o que eles poderiam dizer a respeito e constatamos que: $39 \%$ concordaram com a afirmação; $14 \%$ não concordaram; $7 \%$ concordaram, mas não acreditam que o computador seja instrumento de extrema importância e $40 \%$, a maioria, concordaram com a afirmação, mas assumiram não ter nenhum tipo de fundamentação e/ou argumentos para sustentar a resposta, o que de certa forma faz inferir que a resposta da maioria, $40 \%$, é uma resposta que segue a tendência moderna.

\section{GRÁFICO VIII}

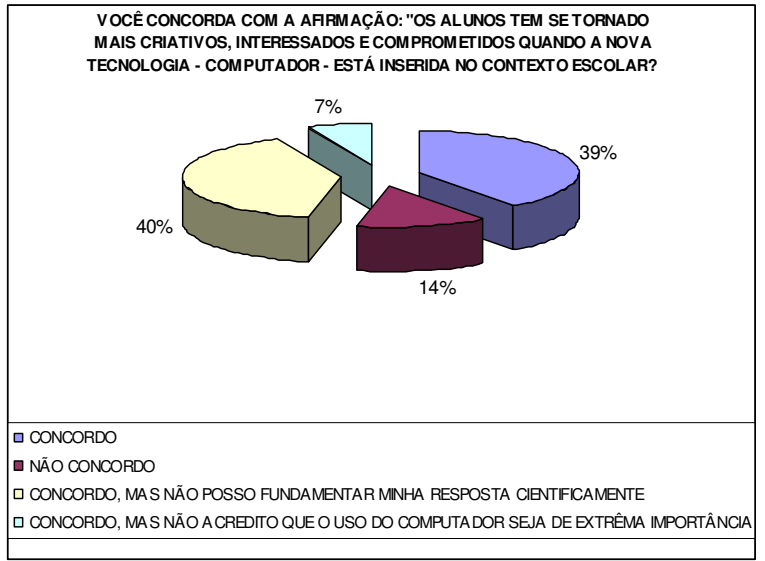

Fonte: Questionário aplicado

Perguntados ainda se eles conheciam algum curso de capacitação que tenha tido incentivo do governo que os capacitasse para a utilização do laboratório de informática da escola, observa-se o resultado a partir do gráfico a seguir. 
GRÁFICO IX

VOCÊ CONHECE ALGUM CURSO DE CAPACITAÇÃO QUE TENHA TIDO INCENTIVO DO GOVERNO PARA QUE VOCÊ POSSA UTILIZAR O LABORATÓRIO DE INFORMÁTICA DA SUA ESCOLA

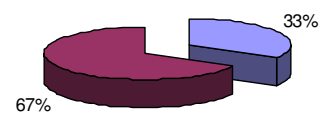

$\square$ SIM $\square$ NÃO

Fonte: Questionário aplicado

$67 \%$ dos entrevistados afirmaram que não conheciam esse tipo de curso, o que causou impacto, pois se esses professores, objetos dessa pesquisa, estão alocados em uma escola que foi contemplada com uma proposta de informatização pelo governo, como não têm conhecimento do assunto.

Tal fato causa ainda maior impacto quando vemos a resposta dada por esses professores acerca do PROINFO, programa de informática do governo.

A mesma porcentagem, 67\%, que afirma não conhecer nenhum tipo de curso que tenha tido incentivo do governo para capacitá-los a utilizarem o laboratório de informática na escola, afirmam categoricamente saber o que é o PROINFO. Uma incoerência entre as respostas. Não seria surpresa se se constatasse que a grande maioria não conhecesse o PROGRAMA.

GRÁFICO $X$

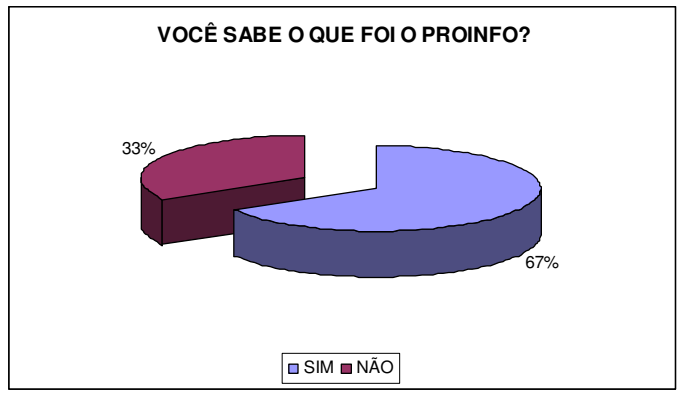

Fonte: Questionário aplicado
Perguntados sobre os aspectos que contribuem para que o computador facilite o desenvolvimento do aluno, os sujeitos da pesquisa responderam que o fascínio que a máquina exerce sobre os jovens é um ponto positivo. O fato de estar concentrado na máquina favorece o passar do tempo, dentre outros aspectos.

Dessa forma, levando em consideração as afirmações feitas anteriormente, perguntou-se então aos professores se eles conheciam algum software específico da sua área de formação, ou melhor, se eles conheciam algum software específico da sua disciplina. Tal foi a surpresa em constatar que a maioria, mesmo acreditando no "poder" exercido pela máquina, não conhecia nenhum software específico da sua disciplina. Observe o gráfico.

\section{GRÁFICO XI}

VOCÊ CONHECE ALGUM SOFTWARE ESPECIFICO DE SUA DISCIPLINA?

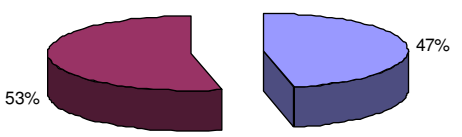

$$
\square \text { SIM } \square N A ̃ O
$$

Fonte: Questionário aplicado

Ainda levando em consideração o software de sua disciplina, perguntamos se eles já haviam trabalhado com algum em suas aulas. O que se pôde constatar é perfeitamente coerente com o resultado apresentado acima, ou seja, 93\% dos entrevistados ainda não utilizou nenhum tipo de software em suas 
aulas, contra $7 \%$, que embora tenham dito que utilizaram, utilizaram apenas um $c d$ room com algumas informações relacionadas ao conteúdo, o que de fato, não caracteriza um software.

\section{GRÁFICO XII}

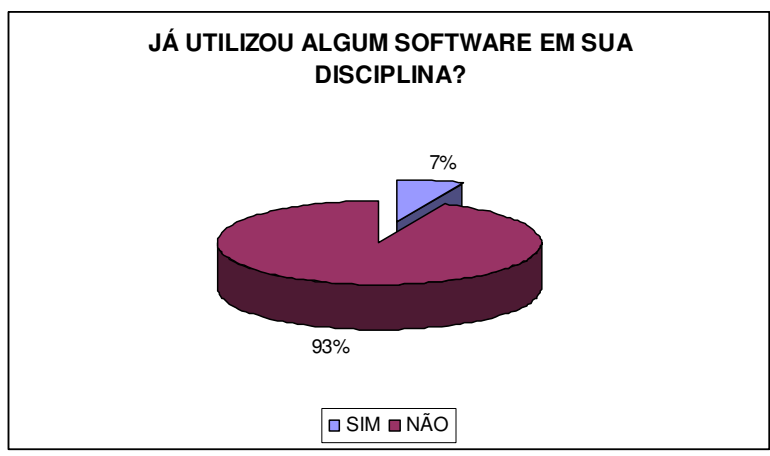

Fonte: Questionário aplicado

Perguntados sobre a crença de que as aulas se tornariam mais atrativas e proveitosas se fossem utilizadas nova tecnologias, nesse caso o computador, os entrevistados foram unânimes. $100 \%$ dos entrevistados acreditam nessa premissa.

\section{GRÁFICO XII}

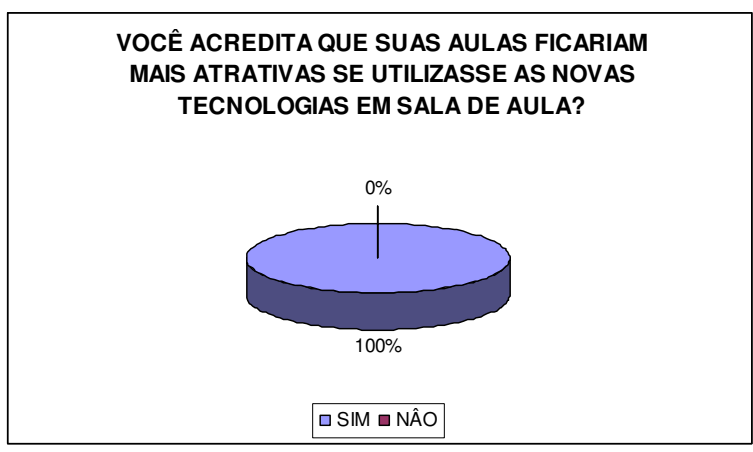

Fonte: Questionário aplicado

Perguntados também sobre a informática como auxílio no processo ensinoaprendizagem, os professores foram categóricos em afirmar que acreditam que tal recurso é um auxílio no desenvolvimento do aluno.

\section{GRÁFICO XIII}

VOCÊ ACREDITA QUE A INFORMÁTICA SE
APRESENTA COMO MEIO AUXILIAR NO APRESENTA COMO MEIO AUXILIAR NO
PROCESSO ENSINO-APRENDIZAGEM?

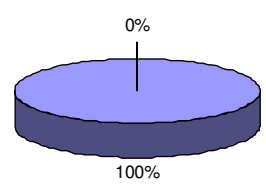

$\square$ SIM $\square N A ̃ O$

Fonte: Questionário aplicado

Em uma última questão, discursiva, perguntamos aos nossos entrevistados se eles se considerariam aptos a utilizarem o laboratório de informática da escola e integrarem essa nova tecnologia as suas aulas, pôde-se perceber a ansiedade, a vontade e a angústia de alguns desses professores em relação à questão. Talvez essa seja a questão que melhor retrate a situação desses professores frente a evolução da tecnologia. E importante informar que não se considerou como a mais importante, mas como a questão que possibilitou aos entrevistados exteriozarem aquilo que, às vezes, não puderam exteriorizar através das questões objetivas. Portanto esta questão torna-se objeto de complementação das outras.

Não cabe aqui simplesmente apontar uma média estatística acerca da resposta dada pelos nossos informantes, mas sim apresentálas e analisa-las.

Uma outro ponto que chama bastante atenção é a resposta dada por um professor que acredita na ideia de integração aula $\mathrm{x}$ 
novas tecnologias, mas se sente despreparada e considera que o ideal seria um treinamento com um profissional da área.

Outros entrevistados afirmam categoricamente que não estão preparados para lidar com a situação, mas estão preparados para adquirirem formação para tal, formação essa que é considerada deficitária por muitos.

Outro ponto extremamente importante, exposto pelos entrevistados é com relação ao laboratório da escola. Alguns computadores estão danificados e falta pessoal habilitado para essa manutenção, uma vez que o governo apenas implanta, mas não acompanha o desenvolvimento.: “... apesar de equipada, o governo não oferece manutenção nunca mais, só instala e não pensa que o computador dá problema, os computadores tem sempre passados por manutenções que às custas de recursos próprios da escola e esforço da direção em manter a rede de pé (...)”.

\section{ANÁLISE DOS RESULTADOS DOS QUESTIONÁRIOS APLICADOS AOS DIRETORES, SUPERVISORES, ORIENTADORES E PEDAGOGOS}

Agora apresentar-se-á os resultados obtidos através da aplicação dos questionários aos diretores, supervisores e pedagogos da escola estadual em estudo. Tal divisão faz-se necessária uma vez que os questionários aplicados eram diferentes e com número de questões diferentes.
Como relatado no capítulo de Metodologia, o questionário aplicado às pessoas que exercem cargo de chefia dentro da escola se difere em um ponto do questionário aplicado aos professores.

Assim, a primeira questão é uma questão de identificação, a partir da qual pôde-se constatar que $50 \%$ do público entrevistado é homem e 50\%, mulher. Ambos estão na faixa etária dos 40 anos e têm o mesmo tempo de formados, ou seja, aproximadamente 13 anos. Sendo um formado em FÍSICA e outro em PEDAGOGIA, respectivamente.

Dando continuidade fez-se a eles as seguintes perguntas, que aqui serão apresentadas apenas em forma de gráfico por se acreditar que estes conseguem demonstrar os resultados obtidos.

\section{GRÁFICO XIV}

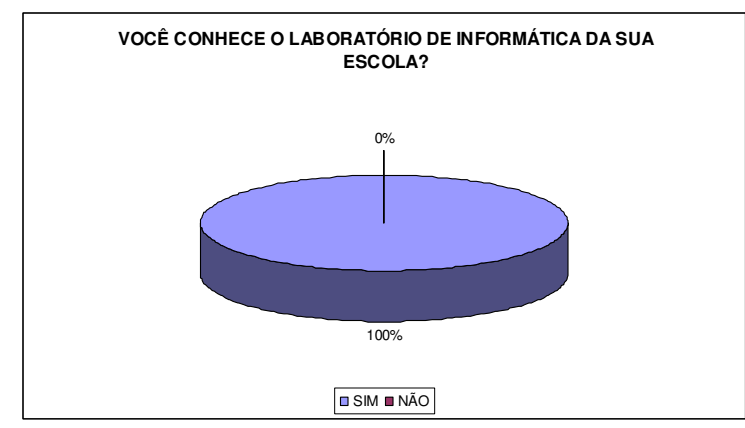

Fonte: Questionário aplicado GRÁFICO XV

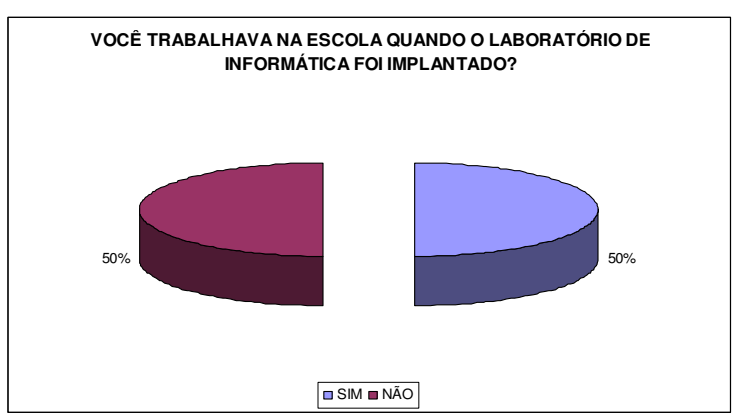

Fonte: Questionário aplicado 


\section{GRÁFICO XVI}

JÁ FEZ ALGUM CURSO ESPECIFICO PARA MANUSEAR O COMPUTADOR?

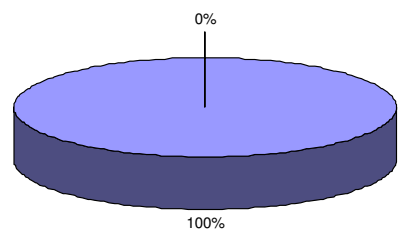

$\square$ SIM $\square N A ̃ O$

Fonte: Questionário aplicado

\section{GRÁFICO XVII}

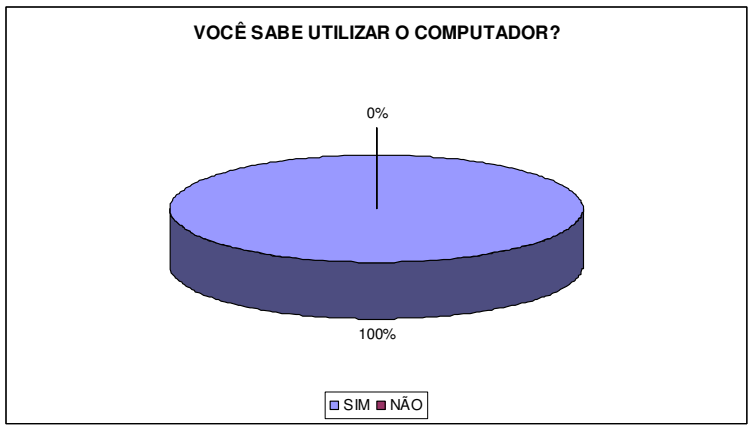

Fonte: Questionário aplicado

\section{GRÁFICO XVIII}

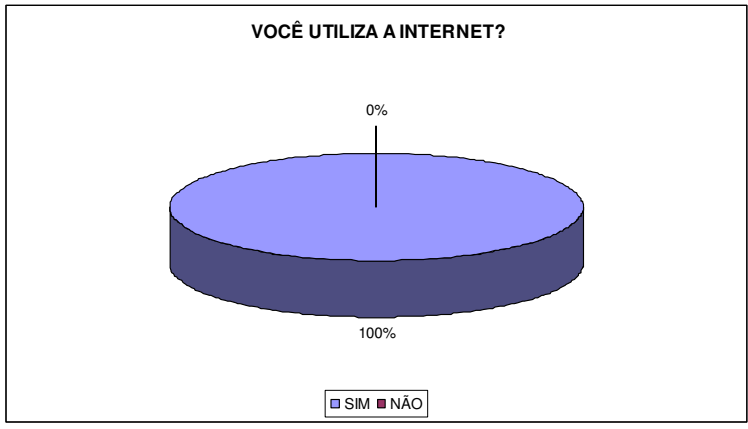

Fonte: Questionário aplicado

\section{GRÁFICO XIX}

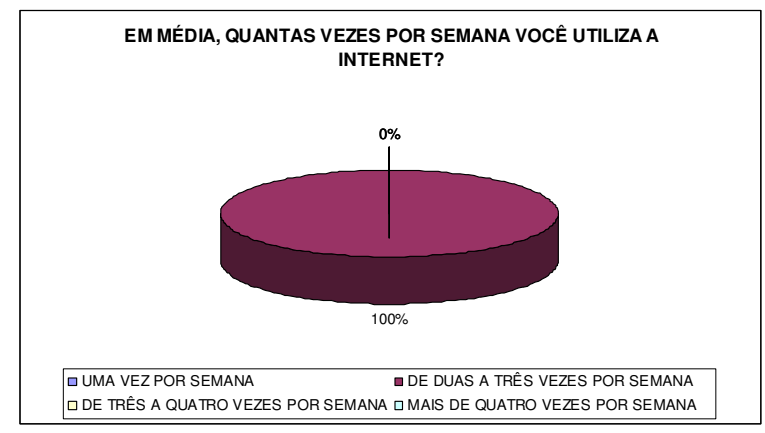

Fonte: Questionário aplicado
GRÁFICO XX

VOCÊ JÁ UTILIZOU O LABORATÓRIO DE INFORMÁTICA DA SUA ESCOLA?

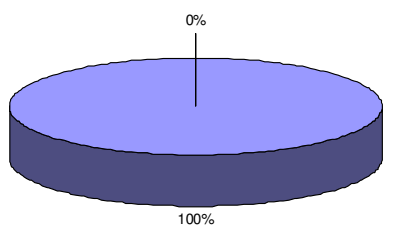

$\square$ SIM घNÃO

Fonte: Questionário aplicado

GRÁFICO XXI

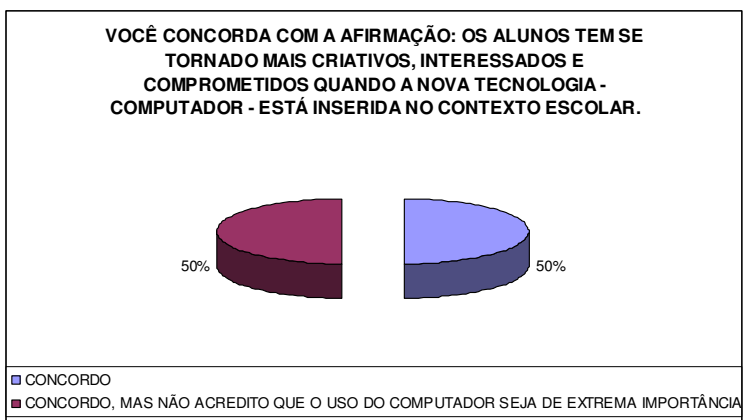

Fonte: Questionário aplicado

\section{GRÁFICO XXII}

VOCÊ CONHECE ALGUM CURSO DE CAPACITAÇÃO QUE TENHA TIDO INCENTIVO DO GOVERNO PARA QUE VOCÊ POSSA UTILIZAR OLABORATORIO DE INFORMATICA DA SUA ESCOLA?
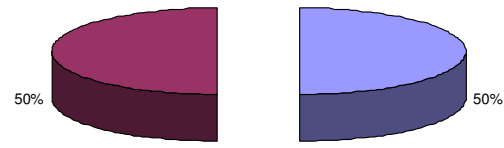

$\square$ SIM $\square N A ̃ O$

Fonte: Questionário aplicado

\section{GRÁFICO XXIII}

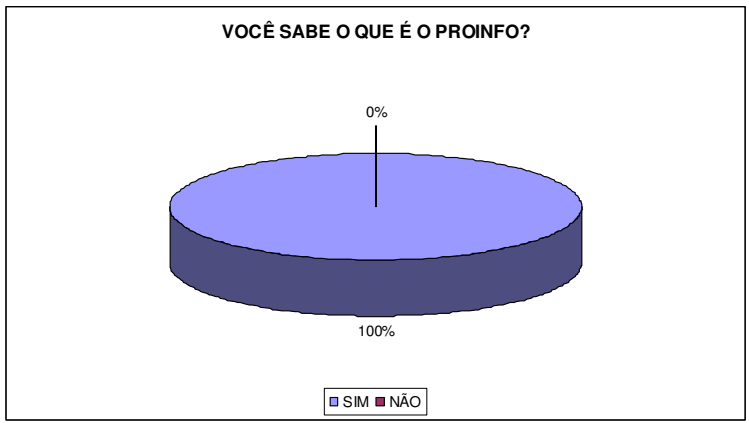

Fonte: Questionário aplicado 


\section{GRÁFICO XXIV}

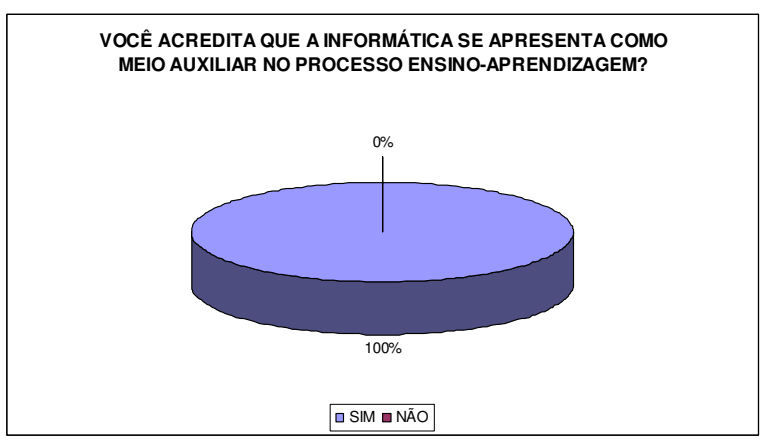

Fonte: Questionário aplicado

Nesse caso, acredita-se que a apresentação dos gráficos seria o suficiente para demonstrar a constatação feita, uma vez que esse público era menor.

Uma questão que chama a atenção é a questão de número 03, representada aqui pelo GRÁFICO XIV, pois pôde-se constatar que o diretor da escola não fazia parte do quadro de funcionários da escola quando o laboratório foi implantado.

Consequentemente a essa questão 03 , fez-se a questão 04, dissertativa, na qual os informantes deveriam descrever o processo de implantação do Laboratório de Informática na escola. Para surpresa, o único informante que pode dar detalhes desse processo foi a supervisora.

De acordo com a supervisora o processo de implantação foi tranquilo e fato de grande comemoração, pois a escola havia sido contemplada com um programa de implantação de Informática na Educação. Ainda de acordo com a supervisora, na época foram treinados dois educadores da escola que ficariam responsáveis por todo o processo de divulgação e acompanhamento do PROINFO. Posteriormente, houve um treinamento para vários educadores da escola com técnicos da Secretaria Estadual de Educação e que talvez o trabalho tenha se perdido em função do trânsito desses responsáveis para as mais diversas escolas.

\section{CONSIDERAÇÕES FINAIS}

A partir dos resultados apresentados na seção APRESENTAÇÃO E ANÁLISE DOS RESULTADOS deste artigo, pôde-se constatar que a introdução de novas tecnologias na educação, especificamente o computador, é uma questão que merece muita atenção e discussão por parte do governo, escola e professores.

Dessa forma, por parte do governo, percebe-se que em um primeiro momento a preocupação é só de implantar o programa na escola e preparação e formação para lidar com o fato é colocada em segundo plano. Por parte dos professores e escola pôde-se constatar ainda, que grande parte dos professores entrevistados acredita na introdução dessa nova tecnologia na educação como uma forma de estimular os alunos e sua construção de conhecimento, mas afirmam não estarem muito familiarizados com o fato e que o melhor caminho seja a formação continuada.

\section{REFERÊNCIAS}

COSTA, José Wilson da; OLIVEIRA, Maria Auxiliadora (orgs). Novas linguagens e novas tecnologias: educação e sociabilidade. Petrópolis, RJ: Vozes, 2004. 
DURKHEIM, Émile. Educação e sociologia. 11. ed. São Paulo: Melhoramentos, 1978.

LÉVY, Pierre. As tecnologias da inteligência; o futuro do pensamento na era da informática. 34. ed. Rio de Janeiro, 1993.

Cibercultura. São Paulo, 1999.

MAGGIO, M.O. O campo da teconologia educacional: algumas propostas para a sua recontextualização, citado por OLIVEIRA et al (2004) “A informática na educaçao". In: Novas Linguagens e Novas Tecnologias: educação e sociabilidade.

MORAN, José Manuel. Internet no ensino.

Comunicação \& Educação. V (14):

janeiro/abril 1999, p. 17-26. NEGROPONTE,

Nicholas. A vida digital. São Paulo:

Companhia das Letras, 2000.

SANCHO, J.M. (org.) (1998). Para Uma tecnologia educacional” , citado por OLIVEIRA et al (2004) “A informática na educaçao. In: Novas Linguagens e Novas Tecnologias: educação e sociabilidade.

MOREIRA, Mércia. O uso do Computador na Educação: Pressupostos psicopedagógicos. Educação em Revista, Belo Horizonte (4): dez 1986.

OLIVEIRA, Celina Couto, COSTA, José Wilson,MOREIRA, Mercia. Ambientes Informatizados de Aprendizagem. Produção e Avaliação de Software Educativo. São Paulo: Papiros Editora,2004.

PIAGET, Jean. Para. Onde vai a Educação. Editora José Olympio. Rio de Janeiro, 1984.

VALENTE, J.A. Por Quê o Computador na Educação?. Campinas, SP: Gráfica da UNICAMP, 1993. 